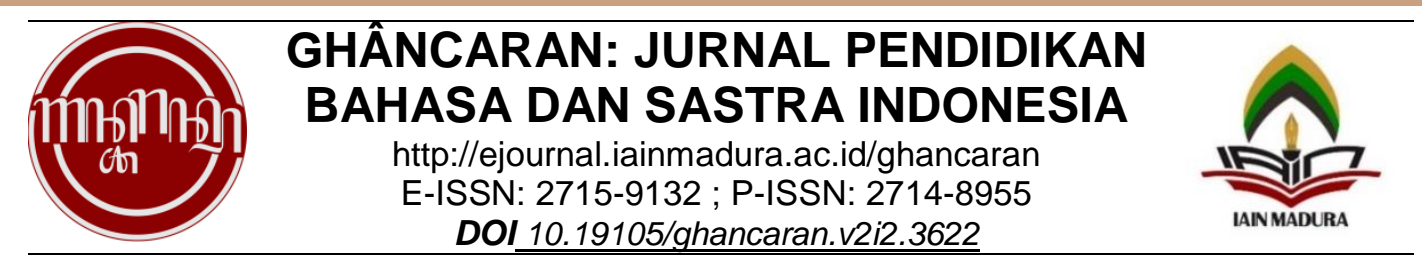

\title{
Gaya Bahasa Perulangan dalam Novel Orang-Orang Biasa Karya Andrea Hirata dan Implikasinya Terhadap Pembelajaran Bahasa Indonesia di SMA
}

\author{
Veni Zakiatun Nabilah", Tri Mulyono**, Syamsul Anwar ${ }^{\star * *}$ \\ *Program Studi Pendidikan Bahasa Sastra Indonesia, Universitas Pancasakti Tegal \\ **Program Studi Pendidikan Bahasa Sastra Indonesia, Universitas Pancasakti Tegal \\ ${ }^{* * *}$ Program Studi Pendidikan Bahasa Sastra Indonesia, Universitas Pancasakti Tegal \\ Alamat surel: venizakiatunnabilah@gmail.com, syamsulanwar590@gmail.com, \\ upstrimulyono@gmail.com
}

\begin{tabular}{l}
\hline \hline \\
\hline Kata Kunci: \\
Gaya Bahasa \\
Perulangan; \\
Novel; \\
Implikasi
\end{tabular}

\begin{abstract}
Abstrak
Penelitian ini bertujuan untuk mendeskripsikan gaya bahasa perulangan dalam novel Orang-Orang Biasa karya Andrea Hirata dan mengetahui implikasi pembelajaran di SMA. Penelitian ini berbentuk deskripsi kualitatif. Metode yang digunakan adalah metode deskripsi kualitatif. Sumber data adalah novel Orang-Orang Biasa. Teknik penyediaan data menggunakan teknik pustaka, teknik baca, dan teknik catat. Data yang diperoleh akan diklasifikasikan, dideskripsikan, dan disajikan menggunakan metode informal. Berdasarkan hasil penelitian dapat disimpulkan bahwa dalam novel $O O B$ menggunakan beberapa gaya bahasa perulangan. Gaya bahasa perulangan tersebut ada sembilan, yaitu aliterasi, asonansi, antanaklasis, epizeukis, anafora, epistrofa, mesodilopsis, epanalepsis, dan anadilopsis. Gaya bahasa perulangan yang paling dominan dalam novel tersebut adalah anafora. Gaya bahasa perulangan yang digunakan Andrea pada novel $O O B$ bertujuan untuk menambah nilai keindahan dalam novel tersebut dengan cara menekankan kata atau frase yang dianggap penting diulang. Hasil penelitian ini dapat diimplikasikan pada pembelajaran bahasa Indonesia di SMA kelas XII semester 1 dengan materi sastra dan pokok bahasan gaya bahasa khususnya
\end{abstract} gaya bahasa perulangan.

\begin{tabular}{|c|c|}
\hline & Abstract \\
\hline $\begin{array}{l}\text { Keywords: } \\
\text { Repetitive } \\
\text { languagestyle; } \\
\text { Novel; } \\
\text { implications }\end{array}$ & $\begin{array}{l}\text { The purpose of this study was to describe the repetitive language } \\
\text { style in Andrea Hirata's Orang-Orang Biasa novel and to find out } \\
\text { the implications of learning repetitive language style in the Orang- } \\
\text { Orang Biasa novel by Andrea Hirata in high school.This research is } \\
\text { in the form of a qualitative description. The method used is a } \\
\text { qualitative description method. The data source is the novel of } \\
\text { Orang-Orang Biasa. The technique of providing data uses library } \\
\text { techniques, reading techniques, and note taking techniques. After } \\
\text { the data is obtained the data is classified then described and } \\
\text { presented using informal methods. The research procedure } \\
\text { consisted of several stages, namely, the planning stage, the } \\
\text { implementation phase, and the data reporting stage.Based on the } \\
\text { results of the study it can be concluded: in the OOB novel a number } \\
\text { of repetitive language styles are used. The repetition language style } \\
\text { includes: alliteration, asonance, antanaclasis, epizeukis, anaphora, }\end{array}$ \\
\hline
\end{tabular}


epistrofa, mesodilopsis, epanalepsis, and anadilopsis. The repetitive language style that is most dominant in the novel is anaphora. The iteration style used by Andrea in the OOB novel is to add value to the beauty of the novel by emphasizing words or phrases that are considered important to be repeated. The results of this study can be implicated in the learning of Indonesian in high school class XII semester 2 with literary material with the subject of language style, especially the repetition language style.

\begin{tabular}{ccc}
\hline Terkirim : 21-07-2020 & ; Revisi: 18-12-2020 & ; Diterima: 01-01-2021 \\
\hline OGhâncaran: JurnalPendidikanBahasadanSastra Indonesia \\
TadrisBahasa Indonesia \\
Institut Agama Islam Negeri Madura, Indonesia
\end{tabular}

\section{PENDAHULUAN}

Keindahan sebuah novel dipengaruhi oleh keterpaduan sebuah unsur intrinsik. Dalam unsur intrinsik terdapat pengolahan bahasa atau gaya bahasa. Bahasa digunakan untuk menyalurkan ide pengarang yang ditulis pada karya sastra yang dibuat, misalnya berupa novel. Abrahams menyebutkan kata novel berawal dari bahasa Italia, yaitu novella yang artinya cerita pendek dalam bentuk prosa. Pada bahasa Latin novel berawal dari novellus turunan dari kata noveis memiliki arti baru (Nurgiyantoro, 2018). Sebagaimana Tarigan (1984) menyatakan baru karena novel datang sesudah berbagai macam sastra lain seperti puisi, drama, dan sebagainya. Khusnin (2012) berpendapat bahwa novel adalah karya seni yang berkaitan dekat dengan aktivitas seseorang dan berupa kisah perjalanan hidup seseorang.

Sebagai karya sastra, novel memiliki pengetahuan yang ditujukan kepada pembaca dan bisa digunakan sebagai bahan acuan serta intropeksi diri. Beragam sifat seseorang serta kisah hidup semua terekam dan tersimpan dalam sebuah karya sastra yang berupa novel. Rekaman tersebut umumnya dikisahkan dalam bentuk konflik permasalahan. Konflik permasalahan tersebut biasanya terjadi antartokoh kemudian dijelaskan oleh pencipta sesuai gaya keinginannya. Nurgiyantoro (2018) membagi novel menjadi tiga jenis, yaitu novel serius, novel populer, dan novel teenlit. Novel memiliki unsur-unsur pembangun yang mampu membentuk sebuah kelengkapan di dalamnya. Masih ada banyak macam unsur pembangun lainnya selain unsur bahasa. Tetapi, secara inti berbagai jenis unsur tercantum secara tradisonal dibagi menjadi dua, yaitu unsur intrinsik dan unsur ekstrinsik.

Andrea Hirata merupakan salah satu penulis di Indonesia yang menghasilkan karya sastra prosa, yaitu novel. Satu diantaranya berjudul Orang-Orang Biasa. Novel ini diterbitkan pada Februari 2019. Novel ini menarik dengan penggunaan bahasa yang sederhana imajinatif. Cerita novel Orang-Orang Biasa diperoleh dari kisah Putri Belianti, yaitu seorang anak yang pintar, tetapi gagal masuk Fakultas Kedokteran, Universitas Bengkulu karena tidak memiliki biaya. la mengemas novel Orang-Orang Biasa menggunakan bahasa sederhana yang imajinatif, tetapi tetap memperlihatkan kualitas pada setiap jalan ceritanya. Pada saat membaca novel Orang-Orang Biasa, pembaca diajak seperti melihat realita masyarakat Indonesia. Pemilihan kata yang sederhana mampu membuat pembaca mengikuti jalan cerita dengan baik.

Salah satu unsur intrinsik dalam novel adalah gaya bahasa. Gaya bahasa disebut juga style atau retorika. Kata style merupakan turunan kata stilus (bahasa Latin), yakni sejenis alat tulis yang digunakan pada lempengan lilin. Tulisan pada lempengan lilin jelas atau tidaknya dipengaruhi oleh kemahiran penulis memakai alat tersebut. Akhirnya pada saat penegasan difokuskan pada kemahiran untuk menulis indah, kemudian style berganti menjadi kecekatan dan keahlian menulis atau menggunakan kata-kata dengan indah (Keraf, 2009). 
Pengolahan bahasa pada novel biasanya disajikan melalui gaya bahasa. Masingmasing penulis mempunyai gaya sendiri pada saat mencetuskan gagasan di setiap tulisannya. Penulis akan mempengaruhi gaya penulisan pada tulisan yang disajikan. Sebuah karya yang diciptakan dipengaruhi oleh watak seseorang yang membuatnya. Hal ini sebagaimana pendapat Keraf (2009) bahwa jiwa dan kepribadian penulis secara khas diperlihatkan pada saat penulis mengungkapkan pikiran melalui bahasa. Secara singkat dapat disebutkan bahwa gaya bahasa ialah cara mengekspresikan gagasan menggunakan bahasa secara khas yang memperhatikan jiwa dan kepribadian penulis (penulis bahasa).

Sebuah gaya bahasa yang baik harus mengandung tiga unsur penting, yaitu kejujuran, sopan santun, dan menarik (Keraf, 2009). Gaya bahasa bisa digolongkan menggunakan bermacam jenis. Setiap penulis membuat pengelompokkan yang berbeda. Tarigan (2013) mengelompokkan gaya bahasa menjadi empat, yaitu gaya bahasa perbandingan, gaya bahasa pertentangan, gaya bahasa pertautan, dan gaya bahasa perulangan. Dalam penelitian ini difokuskan pada gaya bahasa perulangan. Tarigan (2013) membagi gaya bahasa perulangan menjadi 12, hanya saja gaya bahasa perulangan yang ditemukan sebanyak sembilan gaya bahasa perulangan meliputi gaya bahasa aliterasi, gaya bahasa asonansi, gaya bahasa antanaklasis, gaya bahasa epizeukis, gaya bahasa anafora, gaya bahasa epistrofa, gaya bahasa mesodilopsis, gaya bahasa epanalepsis, dan gaya bahasa anadilopsis.

Dengan membaca serta mencari gaya bahasa pada sebuah novel, kosa kata baru akan didapatkan dan diketahui oleh siswa. Hal tersebut tidak terlepas dari kurangnya minat baca yang disebabkan oleh kurangnya pembelajaran di sekolah. Salah satu di antaranya yaitu kurangnya minat baca terhadap sastra. UNESCO menyatakan Indonesia berada pada urutan dua dari bawah mengenai literasi dunia, artinya minat baca di Indonesia masih sangat rendah (Tan, 2020). Dari data tersebut, akhirnya muncul perbandingan minat baca antara siswa di Indonesia dan siswa di luar negeri. Siswa SMA di Indonesia tergolong rendah dalam budaya membaca. Mereka sangat jarang membaca buku secara tuntas. Sedangkan siswa di luar negeri mampu membaca 6 hingga 7 buku, bahkan ada yang sampai puluhan buku.

Mengingat pentingnya pembelajaran sastra sebagai komponen dalam pembelajaran bahasa Indonesia, gaya bahasa berfungsi sebagai bahan ajar serta dapat dijadikan untuk bahan pembelajaran serta mempunyai nilai pendidikan. Novel OrangOrang Biasa karya Andrea Hirata diharapkan bisa dijadikan sebagai alternatif pembelajaran sastra di SMA. Hal tersebut berdasar isi novel yang memiliki gaya bahasa sederhana dan imajinatif. Pengetahuan yang didapatkan dari novel Orang-Orang Biasa karya Andrea Hirata dapat dijadikan untuk mengembangkan kompetensi pengetahuan siswa pada bidang sastra.

Berdasarkan Kompetensi Dasar (KD) materi pengajaran sastra, novel OrangOrang Biasa karya Andrea Hirata mampu dimanfaatkan sebagai pilihan bahan ajar novel Indonesia. Gaya bahasa perulangan yang ada pada novel Orang-Orang Biasa karya Andrea Hirata merupakan bagian dari unsur intrinsik, sehingga gaya bahasa ini berimplikasi terhadap pembelajaran bahasa Indonesia di SMA kelas XII pada Kompetensi Dasar (KD) 3.9 menganalisis isi dan kebahasaan novel.

Terdapat delapan penelitian yang relevan dengan penelitian sebelumnya. Pertama, Khusnin (2012) dengan judul Gaya Bahasa Novel Ayat-Ayat Cinta karya Habiburrahman El Shirazy dan Implementasinya terhadap Pembelajaran Sastra di SMA. Kedua, Murniati (2014) menuliskan hasil penelitiannya dalam sebuah naskah publikasi dengan judul Analisis Repetisi Pada Novel Rembulan Tenggelam di Wajahmu Karya Tere Liye. Ketiga, Razak \& Salleh (2016) meneliti Narrative Rhetoric in Novel Orang Kota Bharu. Keempat, Susilowati (2016) menulis tentang Gaya Bahasa dalam Novel 
Pesantren Impian karya Asma Nadia. Kelima, Setyorini (2016) menulisk artikel dengan judul Analisis Gaya Bahasa dan Nilai Pendidikan Moral dalam Novel Gemuk Sandhi karya Poerwadhie Atmodiharjo. Keenam, Pamungkas \& Saddono (2017) dengan artikel berjudul Repetisi dan Fungsinya dalam Novel di Tanah Lada Karya Ziggy Zezsyazeoviennazabrizkie: Analisis Stilistika. Ketujuh, Melati (2019) yakni artikel dengan judul Kritik Sosial dalam Novel Orang-Orang Biasa karya Andrea Hirata.

Pada penelitian sebelumnya terdapat persamaan dan perbedaan dengan penelitian yang akan dilakukan. Pada penelitian Melati (2019) memiliki sumber yang sama yaitu novel Orang-Orang Biasa karya Andrea Hirata, tetapi berbeda objek yang diteliti. Penelitian tersebut, meneliti tentang kritik sosial yang terdapat dalam novel Orang-Orang Biasa sedangkan penelitian ini tentang gaya bahasa perulangan dalam novel Orang-Orang Biasa. Penelitian tentang gaya bahasa perulangan atau repetisi oleh Pamungkas \& Saddono (2017) dan Murniati (2014) memberikan gambaran tentang penelitian saat ini. Perbedaannya pada penelitian sebelumnya menggunakan metode deskriptif kualitatif dengan teknik analisis isi, sedangkan penelitian ini menggunakan metode deskriptif kulitatif tetapi menggunakan analisis intrinsik beserta implikasi pada pembelajaran di sekolah. Selain itu, ada pula perbedaan dengan penelitian Murniati (2014) yang menggunakan teknik analisis data metode padan dengan teknik dasar pilah unsur penentu (PUP) sedangkan penelitian saat ini menggunakan metode deskriptif kulitatif menggunakan analisis intrinsik. Hasil dari penelitian yang lain juga dapat dijadikan sebagai referensi peneliti dalam melaksanakan penelitian.

Berdasarkan uraian tersebut, penelitian ini bertujuan mendeskripsikan gaya bahasa perulangan dalam novel Orang-Orang Biasa karya Andrea Hirata dan mendeskripsikan implikasi pembelajaran gaya bahasa perulangan dalam novel OrangOrang Biasa karya Andrea Hirata di SMA. Hal itu untuk memperbanyak wawasan keilmuan pada pengajaran bidang bahasa dan sastra. Khususnya tentang gaya bahasa perulangan dan pembelajaran sastra pada sebuah novel. Penelitian ini sebagai alternatif gambaran kepada guru sebagai bahan pembelajaran menganalisis gaya bahasa perulangan dalam novel yang terdapat pada novel Orang-Orang Biasa karya Andrea Hirata terhadap pembelajaran di SMA. Hasil penelitian ini juga diharapkan mampu menjawab permasalahan yang dimunculkan guna mendapatkan hasil yang sesuai. Selain itu, penelitian ini diharapkan mampu memperbanyak pengetahuan pembaca tentang karya sastra yakni novel, serta dapat memahami isi novel Orang-Orang Biasa dan memetik manfaat pada novel tersebut.

\section{METODE}

Penelitian ini menggunakan pendekatan objektif. Pendekatan objektif semata-mata difokuskan pada unsur-unsur, yaitu analisis intrinsik (Ratna, 2004). Selain pendekatan objektif, metode deskripsi kualitatif juga digunakan pada penelitian ini. Dalam penelitian ini menguraikan konsep-konsep pemahaman yang berhubungan, seperti memakai katakata, kalimat-kalimat yang berkaidah pada teori-teori sastra, serta berkaitan dengan novel sebagai objek kajian. Penelitian deskripsi kualitatif bertujuan menguraikan semua indikasi atau keadaan, yaitu keadaan sebenarnya saat melakukan penelitian.

Sumber data primer pada penelitian ini yaitu teks novel Orang-Orang Biasa karya Andrea Hirata cetakan pertama dan diterbitkan pada bulan Februari tahun 2019 oleh penerbit Bentang dengan tebal 300 halaman. Sumber data sekunder ialah sumber data yang ditemukan tidak secara langsung (sumber data pelengkap). Dalam hal ini sumber data sekunder berupa jurnal-jurnal serta buku-buku yang memiliki kaitan terhadap penelitian ini. Kata, kalimat, dan wacana menjadi data yang mengindikasikan adanya gaya bahasa perulangan. 
Pengumpulkan data dalam penelitian ini menggunakan teknik pustaka, baca, dan catat. Data-data yang sudah dikumpulkan sesuai dengan objek penelitian akan diolah, diklasifikasikan, dianalisis, diinterpretasikan, dan ditarik kesimpulan. Data yang sudah selesai dianalisis akan ditarik kesimpulan mengenai gaya bahasa perulangan. Setelah itu, akan diarahkan implikasinya terhadap pembelajaran bahasa Indonesia di SMA Kelas XII semester 2 dengan kompetensi dasar 3.9 menganalisis isi dan kebahasaan novel. Aspek keterampilan berbahasa meliputi kegiatan menyimak, berbicara, membaca, dan menulis. Lingkup materi sastra yakni tentang pembahasan konteks sastra, respons terhadap karya sastra, menilai karya sastra, serta menciptakan karya sastra. Dari aspek tersebut siswa diharapkan mampu mencapai tujuan pembelajaran yang sesuai dengan Kompetensi Dasar (KD).

Berikut ini adalah prosedur yang dilakukan pada saat menganalisis data setelah membaca novel. Pertama, melakukan identifikasi data mengenai gaya bahasa serta diberikan tanda. Kedua, mengklasifikasikan atau mengelompokan data yang sesuai permasalahan. Ketiga, mendeskripsi data berupa gaya bahasa perulangan yang sudah dikelompokkan dalam bentuk kebahasaan. Keempat, menginterpretasi data, yaitu proses menerjemahkan data menggunakan bahasa peneliti sendiri mengenai gaya bahasa perulangan dalam novel Orang-Orang Biasa karya Andrea Hirata.

\section{HASIL DAN PEMBAHASAN}

\section{Gaya Bahasa Perulangan dalam Novel Orang-Orang Biasa Karya Andrea Hirata}

Berdasarkan rumusan masalah, hasil dari penelitian ini meliputi gaya bahasa perulangan dalam novel Orang-Orang Biasa karya Andrea Hirata. Menurut Tarigan (2013) terdapat 12 jenis gaya bahasa perulangan. Namun, dalam penelitian ini ditemukan sembilan gaya bahasa berulangan yang terdapat dalam novel Orang-Orang Biasa karya Andrea Hirata. Berikut merupakan analisis sembilan gaya bahasa perulangan yang terdapat dalam novel Orang-Orang Biasa karya Andrea Hirata.

\section{Aliterasi}

Keraf (2009) menjelaskan aliterasi ialah gaya bahasa berbentuk perulangan konsonan. Sedangkan Tarigan (2013) menyebutkan bahwa gaya bahasa aliterasi biasanya digunakan sebagai pelengkap atau menekankan kata dalam puisi, kadangkadang dalam prosa. Contoh gaya bahasa aliterasi adalah: "Diam diikuti dia". Berikut ini dapat dilihat gaya bahasa aliterai

Segala hal sepakat untuk berdamai. Tupai berdamai dengan kera, kupu-kupu tak ribut dengan kumbang pantat kuning, sibar-sibar bersabar, jalak tak galak, prenjak tak berteriak-teriak, awan berdamai dengan angin, penduduk Kota Belantik berdamai dengan miskin (Hirata, 2019, p. 1).

Dengan membaca kutipan di atas, diketahui bahwa penulis ingin membuat novel tersebut lebih indah dengan menggunakan gaya bahasa perulangan aliterasi, yaitu mengulang konsonan $/ \mathrm{k} /$, ialah pada kata "jalak tak galak" dan "prenjak tak berteriakteriak". Pengulangan konsonan / $/ \mathrm{k}$ itu, dimaksudkan untuk menciptakan suasana damai.

..., kung kang kong-kung kang kong, sabar, teguh, berima-rima, bersahut-sahutan pula dengan kodok-kodok bangkong lainnya. Tak lama kemudian titik-titim halus air hujan tersaput embusan angin dari selatan, tampias ke beranda dan emper-emper toko, .... (Hirata, 2019, p. 5).

Gaya bahasa perulangan aliterasi ditemukan juga pada pengulangan konsonan / $/$ pada kata "kung kang kong-kung kang kong". Pengulangan konsonan yang merupakan 
bentuk onomatope itu, dimaksudkan untuk menciptakan suasana khusuk, karena suara itu bagai mantra memanggil hujan.

\section{Asonansi}

Asonansi merupakan jenis gaya bahasa yang berbentuk perulangan vokal yang sama (Tarigan, 2013). Biasanya dipakai guna mendapatkan kesan penekanan atau menyelamatkan keindahan pada puisi maupun prosa. Contoh asonansi adalah "Singkong rebus dan singkong bakar, belinya di pasar Keramatjati, punya hutang segera dibayar, supaya tidak terbawa mati”.

Peluit menyemprit-nyemprit, sirene meraung-raung, petugas membentak-bentak, para pedagang kaki lima lekas mengemasi dagangan, secepat kilat. Jika ada olimpiade berkemas paling cepat, pasti mereka juara. (Hirata, 2019, p. 28).

Dengan membaca kutipan di atas, diketahui bahwa penulis ingin membuat novel tersebut lebih indah dengan menggunakan gaya bahasa perulangan asonansi, yaitu mengulang vokal /e/, ialah pada kata "Peluit menyemprit-nyemprit" dan "petugas membentak-bentak". Pengulangan vokal /e/ itu, dimaksudkan untuk menciptakan suasana panik.

... Baiklah, Ibu Atikah membuang payungnya sendiri, lalu menangis membuang payungnya sendiri, lalu menangis memanggil-manggil suaminya. Namun, suaranya terlamun debur hujan. Teganya? Setelah segala yang kita lalui bersama? (Hirata, 2019, p. 72).

Sementara itu, pada kutipan di atas ditemukan pengulangan bunyi vokal /a/. Pengulangan vokal itu terdapat pada kalimat "Teganya? Setelah segala yang kita lalui bersama?" pada kalimat terakhir. Pengulangan vokal /a/ tersebut, dimaksudkan untuk menggambarkan suasana sedih penuh dengan penyesalan.

\section{Antanaklasis}

Antanaklasis ialah gaya bahasa yang mengandung ulangan kata yang sama tetapi memiliki makna berbeda (Ducrot dan Todorov, dalam Tarigan 2013). Dalam arti lain antanaklasis ialah gaya bahasa yang memiliki persamaan kata tetapi berbeda makna. Contoh antanaklasis adalah "Panji bisa menaklukan seekor King kobra, meskipun ular tersebut memiliki bisa yang mematikan".

Tak tau bagaimana riwayatnya, tau-tau rusip sudah ada di bangku belakang dan tak seorangpun, anak bodoh, anak pintar, anak baik, anak nakal, yang mau dekat-dekat dengannya sebab jika dia lewat, macam pasar ikan lewat (Hirata, 2019, p. 8).

Dengan membaca kutipan di atas, diketahui bahwa penulis ingin membuat novel tersebut lebih indah dengan menggunakan gaya bahasa perulangan antanaklasis yaitu dengan mengulang kata yang sama akan tetapi tidak memiliki arti yang sama. Pengulangan tersebut ada pada kata "anak" pada penggalan novel Orang-Orang Biasa. Kata "anak" pertama memiliki arti anak yang bodoh, kata "anak" kedua memiliki arti anak yang pintar, kata "anak ketiga memiliki arti anak yang baik, dan kata "anak" keempat memiliki arti anak yang nakal. Pengulangan kata "anak" dimaksudkan untuk menggambarkan keadaan memilukan. 
Yang dicemaskan adalah jika jumlah perampok itu banyak, bersenjata tajam, atau malah bersenjata api. Jika mereka berani merampok, tentu mereka orang kejam yang tak pernah ragu bertindak, sedangkan dia hanya berdua dengan inspektur (Hirata, 2019, p. 157).

Sementara itu, pada kutipan di atas juga ditemukan gaya bahasa perulangan antanaklasis. Kutipan di atas dapat disimpulkan bahwa penulis ingin membuat novel tersebut lebih indah dengan menggunakan gaya bahasa antanaklasis yaitu dengan mengulang kata yang sama akan tetapi tidak memiliki arti yang sama. Pengulangan tersebut ada pada kata "bersenjata" pada penggalan novel Orang-Orang Biasa. Kata "bersenjata" pertama memiliki arti menggunakan senjata tajam seperti pisau, pedang, golok sedangkan kata "bersenjata" kedua memiliki arti menggunakan senjata api seperti senapan dan pistol.

\section{Epizeukis}

Epizeukis adalah gaya bahasa yang mengulang secara langsung, yaitu berupa penekanan kata yang dianggap penting diulang secara berturutan (Tarigan, 2013). Dari pendapat tersebut maka bisa dikatakan bahwa epizeukis ialah gaya bahasa perulangan yang menekankan kata penting dengan berturutan. Contoh epizeukis adalah "Bapak ibu semua, Sheila memang pantas mendapatkan beasiswa, pantas mendapatkan beasiswa, pantas mendapatkan beasiswa, karena dia memiliki kemampuan akademik yang luar biasa".

Namun, sekolah lain tak ada yang mau menerima mereka. Atas nama kemanusiaan, mereka diterima kembali di sekolah kampung ini dan ditempatkan duduknya di bangku paling belakang dari yang paling belakang (Hirata, 2019, p. 7).

Gaya bahasa anafora juga ditemukan pada kutipan di atas, yaitu terdapat pada pengulangan kata "polisi". Pengulangan kata "polisi" ditemukan pada kalimat "Polisi tak boleh duduk diam saja. Polisi itu tidak hanya mengetik dan menekan surat, polisi harus mengintai". Pengulangan kata tersebut digunakan sebagai penekanan untuk kata yang dianggap penting sehingga membuat bacaan novel tersebut menjadi lebih indah. Pengulangan kata "polisi" dimaksudkan untuk menggambarkan suasana siap siaga.

\section{Epistrofa}

Epistrofa adalah gaya bahasa berupa pengulangan kata pada akhir baris atau kalimat teratur (Tarigan, 2013). Dari pendapat tersebut dapat dikatakan bahwa epifora yaitu gaya bahasa perulangan yang merepetisi kata akhir pada setiap baris atau kalimat. Contoh epistrofa adalah "Semua baktiku kupersembahkan untuk Indonesia, semua usahaku kupersembahkan untuk Indonesia, jiwa dan ragaku kupersembahkan untuk Indonesia".

Sebab, Inspektur berkacamata gaya pustakawan dan berwajah jenaka. Jika dia tersenyum, matanya ikut tersenyum. Jika dia tidak tersenyum, matanya tetap tersenyum. Dia percaya diri, luwes, dan berjiwa humor (Hirata, 2019, p. 12).

Dengan membaca kutipan di atas, diketahui bahwa penulis ingin membuat novel tersebut lebih indah dengan menggunakan gaya bahasa epistrofa yaitu dengan mengulang kata atau frase disetiap akhir kalimat atau baris. Pengulangan tersebut tersebut terdapat pada kata "tersenyum". Kata "tersenyum" ditemukan pada kalimat "Jika dia tersenyum, matanya ikut tersenyum. Pengulangan kata "tersenyum" dimaksudkan untuk menggambarkan suasana senang. 
Tak ada yang bicara, senyap. Bukan karena dilarang bicara, melainkan karena terlalu gugup untuk bicara. Sepanjang jalan mereka melihat orang-orang yang mau ikut pawai, berbondong bondong dengan berbagai kostum (Hirata, 2019, p. 178).

Gaya bahasa epistrofa juga ditemukan pada kutipan di atas, yaitu berbentuk pengulangan kata "bicara". Pengulangan kata "bicara" ditemukan pada kalimat "Bukan karena dilarang bicara, melainkan karena terlalu gugup untuk bicara" yang terletak pada kalimat kedua. Pengulangan kata tersebut digunakan sebagai penekanan untuk kata yang dianggap penting, sehingga membuat bacaan novel tersebut menjadi lebih indah. Pengulangan kata "bicara" dimaksudkan untuk menggambarkan suasana senyap.

\section{Mesodilopsis}

Mesodilopsis adalah gaya bahasa repetisi yang berwujud kata atau frase yang diulang ditengah-tengah baris atau beberapa kalimat berurutan (Tarigan, 2013). Dari pendapat tersebut dapat disimpulkan bahwa mesodilopsis ialah gaya bahasa perulangan yang merepetisis kata atau frasa yang ditengah baris atau kalimat. Contoh mesodilopsis adalah "Indonesia membutuhkan orang-orang tangguh, Indonesia membutuhkan orang-orang pintar, Indonesia membutuhkan orang-orang jujur".

Ajaib, satu demi satu rencananya mulai jatuh pada tempatnya. Benar pepatah sejuta umat sepanjang zaman itu: Di mana ada kemauan, di situ ada jalan. Tak ada ombak, tak ada angin, tahu-tahu dibangun kompleks ruko di kawasan yang menjanjikan untuk membuka warung kopi (Hirata, 2019, p. 120).

Dengan membaca kutipan di atas, diketahui bahwa penulis ingin membuat novel tersebut lebih indah dengan menggunakan gaya bahasa mesodilopsis yaitu berupa pengulangan kata atau frase disetiap tengah kalimat atau baris yang berurutan. Perulangan tersebut ada pada kata "ada". Pengulangan tersebut terdapat pada kata "ada". Kata "ada" ditemukan pada kalimat "Di mana ada kemauan, di situ ada jalan" yang terdapat pada kalimat kedua. Perulangan tersebut ada pada kata "ada". Pengulangan kata tersebut digunakan sebagai penekanan untuk kata yang dianggap penting sehingga membuat bacaan novel tersebut menjadi lebih indah. Pengulangan kata "ada" dimaksudkan tidak lain yaitu menjelaskan tentang sebuah peribahasa yang memiliki arti seseorang yang mempunyai niat serta mau berusaha dalam menggapai sesuatu, pasti akan selalu ada cara untuk mendapatkannya.

Ibu Atikah ikut bernyanyi mengikuti radio, kedua anaknya ikut bernyanyi dan menari-nari. Musik mengentak seirama kibar umbul-umbul sepanjang jalan, lenggak-lenggok orang yang berlalu-lalang dan gelak tawa anak-anak sekolah yang berlari riang (Hirata, 2019, p. 220).

Gaya bahasa mesodilopsis juga ditemukan pada kutipan di atas, yaitu berupa pengulangan kata "bernyanyi". Kata bernyanyi ditemukan pada kalimat "lbu Atikah ikut bernyanyi mengikuti radio, kedua anaknya ikut bernyanyi dan menari-nari” yang terletak pada kalimat pertama. Pengulangan kata tersebut digunakan sebagai penekanan untuk kata yang dianggap penting, sehingga membuat bacaan novel tersebut menjadi lebih indah. Pengulangan kata "bernyanyi" dimaksudkan untuk menggambarkan suasana senang.

\section{Epanalepsis}

Epanalepsis adalah gaya bahasa pengulangan kata pertama dari baris, klausa, atau kalimat kemudian diulang di akhir (Tarigan, 2013). Dari pendapat tersebut bisa 
dikatakan bahwa simploke merupakan gaya bahasa perulangan yang mengulang kata pertama menjadi kata terakhir. Contoh epanalepsis adalah "Shinta akan membelikan rumah untuk orang tua Shinta".

"Negatip! Negatip! Tak ada siapa-siapa, Kumendan!"

"Dermaga, Sersan! Perampok di Dermaga! Lekas! Tolong saya, Sersan! Tolong!"

"Siaphhh ... Kumendan!" (Hirata, 2019, p. 158).

Dengan membaca kutipan di atas, diketahui bahwa penulis ingin membuat novel tersebut menjadi lebih indah menggunakan gaya bahasa epanalepsis yaitu dengan mengulang kata atau frase pertama ke akhir kalimat. Pengulangan tersebut terjadi pada kata "dermaga". Kata "dermaga" ditemukan pada kalimat "Dermaga, Sersan! Perampok di Dermaga" yang terletak pada kalimat kedua. Pengulangan kata tersebut digunakan sebagai penekanan untuk kata yang dianggap penting, sehingga membuat bacaan novel tersebut menjadi lebih indah. Pengulangan kata "dermaga" dimaksudkan untuk menjelaskan sebuah tempat.

\section{Anadilopsis}

Anadiplosis merupakan gaya bahasa pengulangan kata atau frase terakhir dari suatu klausa atau kalimat menjadi kata atau frase pertama dari klausa atau kalimat selanjutnya (Tarigan, 2013). Dari pendapat tersebut bisa dikatakan bahwa simploke ialah gaya bahasa yang menghasilkan kata pertama dari kata terakhir pada kalimat melalui perulangan. Contoh anadiplosis adalah "Saat kasih berubah menjadi cinta, saat cinta berubah menjadi tulus, saat tulus berubah menjadi perjuangan, saat perjuangan berubah menjadi harapan".

Sesungguhnya selalu ada lelaki dalam setiap lelaki. Lelaki di dalam diri Bastardin dan boron adalah lelaki jahat. Lelaki dalam diri salud adalah lelaki lembut yang baik hati (Hirata, 2019, p. 20).

Dengan membaca kutipan di atas, diketahui bahwa penulis ingin membuat novel tersebut lebih indah menggunakan gaya bahasa anadilopsis yaitu dengan mengulang kata atau frase di akhir kalimat atau baris menjadi di awal kalimat berikutnya. Pengulangan tersebut terdapat pada kata "lelaki". Kata "lelaki" ditemukan pada kalimat "Sesungguhnya selalu ada lelaki dalam setiap lelaki. Lelaki di dalam diri Bastardin dan boron adalah lelaki jahat". Pengulangan kata tersebut digunakan sebagai penekanan untuk kata yang dianggap penting, sehingga membuat bacaan novel tersebut menjadi lebih indah. Pengulangan kata "lelaki" dimaksudkan untuk menggambarkan sebuah sifat lelaki.

Teringat Aini akan kata-kata perawat rumah sakit umum itu, bahwa hanya dokter ahli yang bisa tahu penyakit ayahnya itu. Dokter ahli, siapakah mereka? Di manakah mereka? mereka bak pengejawantahan sesuatu asing dan jauh bagi Aini, sesuatu yang tak terjangkau (Hirata, 2019, p. 33).

Gaya bahasa anadilopsis juga ditemukan pada kutipan di atas, yaitu terletak pada kata "mereka". Kata "mereka" ditemukan pada kalimat "Di manakah mereka? mereka bak pengejawantahan sesuatu asing dan jauh bagi Aini". Pengulangan tersebut ada pada kata "mereka". Perulangan kata tersebut digunakan sebagai penekanan untuk kata yang dianggap penting sehingga membuat bacaan novel tersebut menjadi lebih indah. Pengulangan kata "mereka" dimaksudkan untuk menjelaskan ketidaktahuan tentang dokter ahli 


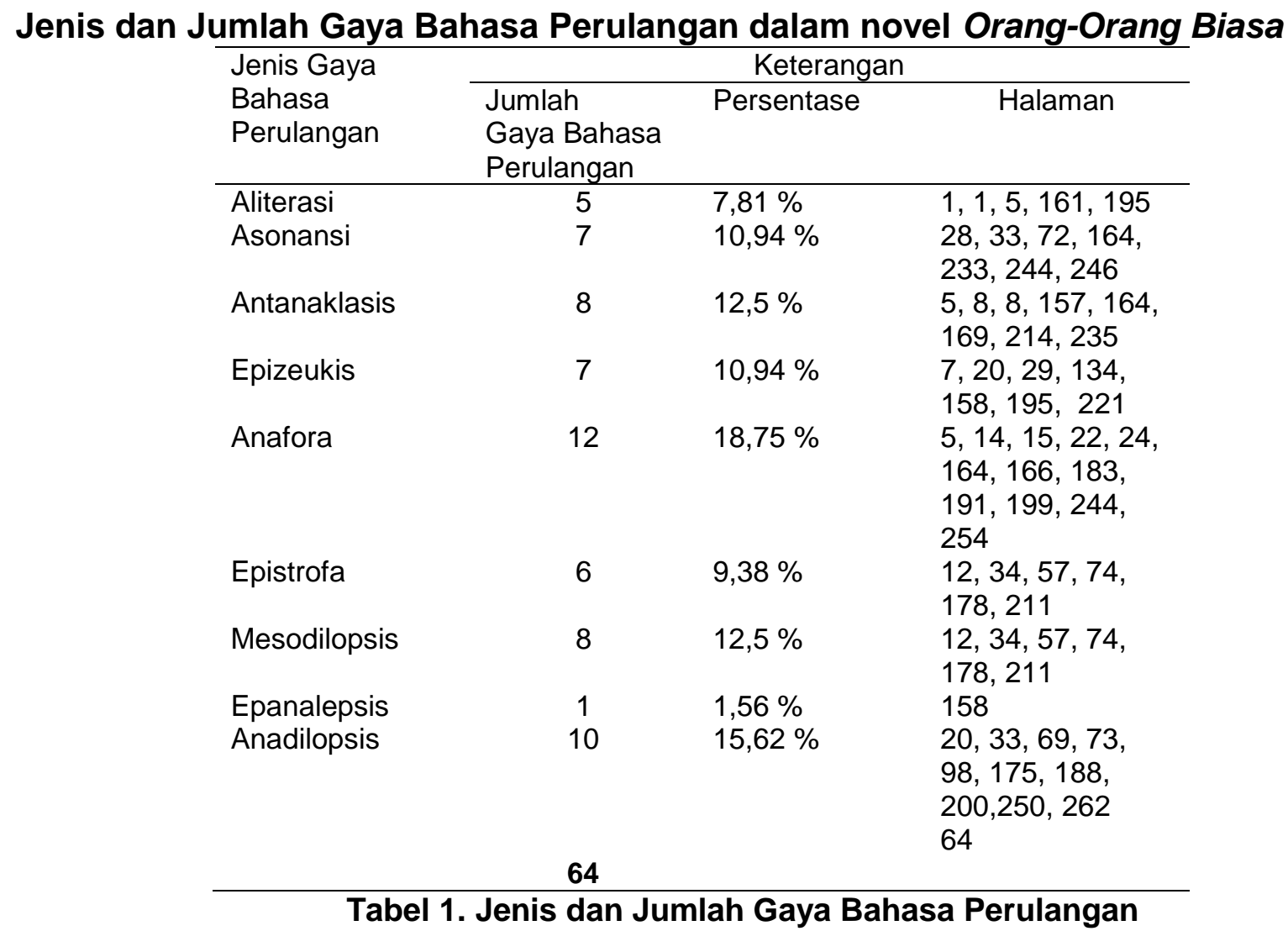

Berdasarkan tabel gaya bahasa perulangan di atas, jenis gaya bahasa perulangan yang paling dominan atau lebih sering diperlihatkan dalam novel Orang-Orang Biasa karya Andrea Hirata adalah jenis gaya bahasa perulangan anafora yaitu memiliki 12 data, kemudian disusul oleh gaya bahasa perulangan anadilopsis sebanyak 10 data.

\section{Implikasi Hasil Penelitian terhadap Pembelajaran Bahasa Indonesia di SMA}

Hasil penelitian ini mempunyai hubungan dengan pembelajaran bahasa Indonesia di SMA. Salah satu pembelajaran bahasa Indonesia adalah berkaitan dengan pembelajaran sastra. Pembelajaran sastra berbeda dengan pembelajaran lain yang bersifat konkret atau nyata (yang dapat diketahui serta diselidiki dengan berdasarkan percobaan sehingga dapat dibuktikan dengan pasti). Pembelajaran sastra memerlukan kehadiran sebuah intuisi, imajinasi, serta daya kreativitas sehingga membuat siswa berkesan pada saat mengikuti pembelajaran sastra. Tujuan pembelajaran sastra di sekolah yaitu untuk membina individu-individu agar memiliki keterampilan, pengetahuan, dan kepribadian sesuai dengan norma-norma.

Penelitian perihal gaya bahasa perulangan dalam novel Orang-Orang Biasa karya Andrea Hirata dapat diimplikasikan pada pembelajaran bahasa Indonesia di SMA Kelas XII semester 2 dengan kompetensi dasar 3.9 menganalisis isi dan kebahasaan novel. Aspek keterampilan berbahasa meliputi: menyimak, berbicara, membaca, dan menulis dan lingkup materi sastra melingkupi pembahasan konteks sastra, respons terhadap karya sastra, menilai karya sastra, serta menciptakan karya sastra. Dari aspek tersebut siswa diharapkan mampu mencapai tujuan pembelajaran yang sesuai dengan kompetensi dasar. Indikator pencapaian kompetensi meliputi enam aspek yaitu, (1) menemukan isi (unsur intrinsik dan ekstrinsik) dan kebahasaan (ungkapan, majas, peribahasa) novel, (2) menyusun novel berdasarkan rancangan, (3) mempresentasikan, (4) mengomentari, dan (5) merevisi unsur-unsur intrinsik dan kebahasaan novel, dan (6) 
menyusun hasil pengkajian novel. Pada penelitian ini penulis hanya fokus pada unsur intrinsik yaitu tentang gaya bahasa perulangan.

\section{SIMPULAN}

Hasil analisis terhadap novel Orang-Orang Biasa karya Andrea Hirata dapat memberikan pelajaran yang baik dan ilmu pendidikan guna menambah pelajaran baru tentang gaya bahasa perulangan untuk siswa kelas XII dengan materi novel. Gaya bahasa perulangan dalam novel Orang-Orang Biasa karya Andrea Hirata dapat menambah wawasan baru berdasarkan pada pemahaman gaya bahasa perulangan yang berupa aliterasi, asonansi, antanaklasis, epizeukis, anafora, epistrofa, mesodilopsis, epanalepsis, dan anadilopsis.

Analisis tentang gaya bahasa perulangan dalam novel Orang-Orang Biasa karya Andrea Hirata juga dapat digunakan sebagai bahan pertimbangan dalam menentukan dan memilih karya sastra yang berkualitas dan layak untuk diajarkan kepada siswa di SMA. Novel Orang-Orang Biasa sesuai dibaca siswa SMA karena di dalamnya memiliki bahasa yang menarik. Dengan membaca novel ini para guru dapat mengajak siswa untuk berfikir positif melalui gaya bahasa yang disampaikan. Hal ini dapat menentukan sikap siswa menjadi lebih baik. Tujuan pembelajaran bahasa dan satra Indonesia untuk membekali siswa dengan kemampuan minimal dalam meningkatkan kebahasaan, pengetahuan, kemampuan, siswa dan keterampilan sehingga siswa dapat berprestasi dan mampu berfikir positif terhadap bahasa dan sastra Indonesia. Secara garis besar dalam pembelajaran bahasa Indonesia adalah mengajarkan materi dalam beberapa komponen untuk menunjang siswa dalam mengerjakan mata pelajaran yang diberikan oleh pengajar.

\section{DAFTAR RUJUKAN}

Hirata, A. (2019). Orang-Orang Biasa. Bentang Pustaka.

Keraf, G. (2009). Diksi dan Gaya Bahasa. Gramedia Pustaka Utama.

Khusnin, M. (2012). Gaya Bahasa Novel Ayat-Ayat Cinta Karya Habiburrahman El Shirazy dan Implementasinya Terhadap Pengajaran Sastra di SMA. Seloka - Jurnal Pendidikan Bahasa Dan Sastra Indonesia, 1(1). https://doi.org/10.15294/seloka.v1i1.121

Melati, I. K. (2019). Kritik Sosial dalam Novel Orang-Orang Biasa Karya Andrea Hirata. Prosiding Seminar Nasional Bahasa Dan Sastra (SENASBASA), 3(2). http://research-report.umm.ac.id/index.php/

Murniati, R. P. (2014). Analisis Repetisi Pada Novel Rembulan Tenggelam Di Wajahmu Karya Tere-Liye. Universitas Muhammadiyah Surakarta.

Nurgiyantoro, B. (2018). Teori Pengkajian Fiksi. UGM Press.

Pamungkas, S. A., \& Saddono, K. (2017). Repetisi dan Fungsinya dalam Novel di Tanah Lada Karya Ziggy Zezsyazeoviennazabrizkie: Analisis Stilistika . Metasastra: Jurnal Penelitian Sastra, $11(1)$

113-130. https://doi.org/10.26610/metasastra.2018.v11i1.113-130

Ratna, I. N. K. (2004). Teori, Metode, dan Teknik Penelitian sastra: dari Strukturalisme Hingga Postrukturalisme: Perspektif Wacana Naratif. Pustaka Pelajar.

Razak, N. A., \& Salleh, C. A. (2016). Retorik Naratif dalam Novel "Orang Kota Bharu." International Journal of the Malay World and Civilasation (Iman), 13-22. https://doi.org/10.17576/IMAN-2016-0402-02

Setyorini, Y. (2016). Analisis Gaya Bahasa dan Nilai Pendidikan Moral dalam Novel Gumuk Sandhi Karya Poerwadhie Atmodihardjo [PBSJ-FKIP]. http://repository.umpwr.ac.id:8080/handle/123456789/1740

Susilowati, E. (2016). Gaya Bahasa dalam Novel Pesantren Impian karya Asma Nadia. 
Veni Zakiatun Nabilah, Tri Mulyono, Syamsul Anwar

$\begin{array}{lllll}\text { Jurnal Bastra } & \text { (Bahasa } & \text { Dan } & \text { Sastra), } & \text { 1(2) }\end{array}$

http://ojs.uho.ac.id/index.php/BASTRA/article/view/1511

Tan, P. (2020, March 14). Minat Baca Orang Indonesia Paling Rendah di Dunia, Karena

Tak Ada Akses dan Kesempatan. Konde.Co Media for Women and Minority. https://www.konde.co/2020/03/minat-baca-orang-indonesia-paling.html/

Tarigan, H. G. (1984). Prinsip-Prinsip Dasar Sastra. Penerbit Angkasa.

Tarigan, H. G. (2013). Pengajaran Gaya Bahasa. Penerbit Angkasa. 